\title{
Expression of the RNA methyltransferase Nsun5 is essential for developing cerebral cortex
}

\author{
Peipei Chen ${ }^{1,2+}$, Tingting Zhang ${ }^{1,2+}$, Zihao Yuan ${ }^{2}$, Bin Shen ${ }^{1 *}$ and Ling Chen ${ }^{1,2^{*}}$ (D)
}

\begin{abstract}
Nsun5 gene, encoding a cytosine-5 RNA methyltransferase, is deleted in about 95\% patients with Williams-Beuren syndrome (WBS). WBS is a neurodevelopmental disorder and characterized by cognitive disorder. We generated single-gene Nsun5 knockout (Nsun5-KO) mice and reported that the Nsun5 deletion leads to deficit in spatial cognition. This study focused on investigating the influence of Nsun5 deficiency in the development of cerebral cortex. In comparison with wild-type littermates, the cortical thickness in postnatal day 10 Nsun5-KO mice was obviously reduced with an abnormal laminar organization, and the processes of pyramidal cells were shorter and finer. Nsun5 was selectively expressed in radial glial cells (RGCs) of cerebral cortex from embryonic day (E) 12.5 to E16.5, but not in intermediate progenitor cells (IPCS) or neocortical neurons. The Nsun5 deletion did not alter proliferation of RGCs or differentiation of RGCs into IPCs. Notably, the ablation of Nsun5 disrupted the growth of radial glial scaffolds, thus numerous basal processes of RGCs failed to reach pial basement membrane. Level of cell polarity regulator $\mathrm{Cdc} 42$ protein in radial glial scaffolds of E14.5 Nsun5-KO mice was reduced, but the level of Cdc42 mRNA was unchanged. The dysfunction of glial scaffolds impeded the radial migration of upper-layer and deeperlayer neurons to cause their subcortical accumulation and apoptosis, resulting in an obvious thinness of the cortical plate in E18.5 Nsun5-KO mice. These findings establish a critical role of Nsun5 in development of cerebral cortex through regulating radial glial scaffolds of RGCs to control migration of neocortical neurons.
\end{abstract}

Keywords: Cerebral cortex, Migrating neurons, Nsun5, Radial glial cells (RGCs), Williams-Beuren syndrome (WBS)

\section{Introduction}

Williams-Beuren syndrome (WBS) is a contiguous gene deletion disorder [1] that is caused by spontaneous deletions of 1.5 million to 1.8 million base pairs comprising 26 to 28 genes on human chromosome $7 \mathrm{q} 11.23$ [2]. Using probes containing parts of the elastin gene, the deletion has readily been detected in approximately 90-99\% WBS patients [3].

WBS is characterized by an unusual cognitive profile that includes relatively preserved expressive language, facial processing abilities and dramatic deficits in spatial cognition [4-6]. Processing of spatial navigational information and long-term memory, domains highly

\footnotetext{
* Correspondence: lingchen@njmu.edu.cn; binshen@njmu.edu.cn

${ }^{\dagger}$ Peipei Chen and Tingting Zhang contributed equally to this work.

${ }^{1}$ State Key Laboratory of Reproductive Medicine, Nanjing Medical University,

Tianyuan East Road 818, Nanjing, China

Full list of author information is available at the end of the article
}

dependent on hippocampal and cortical function, are also severely affected in WBS [7]. In mice, the entire region of the WBS deletion is conserved on chromosome band $5 \mathrm{G} 2$ in a reverse orientation to the centromere and the flanking genes [8]. Most of the genes affected by the WBS deletion are expressed in the brain. Several mouse models have been generated by the single-gene knockout of deleted WBS loci, but relevant phenotypes of neurocognitive features are only evident in three heterozygous Cyln2, Gtf2i, and Gtf2ird1 knockout mouse models [9-11].

The Nsun5 gene, which encodes a cytosine-5 RNA methyltransferase, is included in the WBS deletion $[2,12]$. The deletion of Nsun 5 has been reported in about 95\% patients with WBS [2]. Zhang et al. have recently reported that single-gene Nsun5 knockout homozygous (Nsun5$\mathrm{KO}$ ) mice show the phenotype of spatial cognitive defects [13]. The whole brain volume in patients with WBS has been reported to be reduced by 13\% [14]. Mice with

(C) The Author(s). 2019 Open Access This article is distributed under the terms of the Creative Commons Attribution 4.0 International License (http://creativecommons.org/licenses/by/4.0/), which permits unrestricted use, distribution, and 
partial (approximately half) deletions of the WBS loci showed reductions in brain weight [15] or brain size [16]. Human Nsun5 is reported to co-precipitate with ribosomes [17]. In yeast cells, Nsun 5 has been found to directly methylate cytosine 2278 (C2278) of $25 \mathrm{~S}$ rRNA $[18,19]$. The lack of this methylation step leads to a decrease in translational fidelity and a increase in the recruitment of stress-specific mRNAs to translating ribosomes [20]. A loss-of-function mutation in human NSUN2, which encodes a tRNA methyltransferase, causes neurodevelopmental defects including microcephaly [21, 22]. Nsun 2 knockout in mice causes a neuro-cognitive defect [23]. The Nsun5 transcript is enriched in the developing mouse brain [24]. However, it remains unknown whether Nsun5 deletion affects the development of brain.

The mammalian cerebral cortex is a well-organized structure containing layer-specific classes of neurons and glial cells [25]. The cortical neurons and glia arise from a small heterogeneous population of neural progenitor cells, including radial glial cells (RGCs) in ventricular zone (VZ) and intermediate progenitor cells (IPCs) in subventricular zone (SVZ). RGCs produce both upper-layer neurons and deeper-layer neurons directly or indirectly through IPCs [26]. Thus, the transition from RGCs to IPCs plays a key role in determining the total number of neurons [27]. In developing cerebral cortex, the glial scaffold and molecular polarity of RGCs serve as a critical migratory guide for upper-layer neurons and deeper-layer neurons.

The present study focused on investigating the effects of Nsun 5 deficiency on the development of cerebral cortex and the underlying mechanisms. Our results showed that Nsun 5 was selectively expressed in RGCs during the developing cerebral cortex. The Nsun5 deficiency impaired the glial scaffold and polarity of RGCs to impede migration of neocortical neurons, which disturbed the laminar organization of neocortical neurons and the development of pyramidal cells.

\section{Results}

\section{Generation of Nsun5-KO mice}

In comparison with WBS genomic region in human, the entire WBS deletion gene order in mouse shows a reverse orientation (Fig. 1a). The Nsun5 gene has been determined to include in the 28 genes of WBS deletion $[2,12]$. To investigate the influence of Nsun 5 deficiency in the development of cerebral cortex, we used CRISPR/ Cas9 genome editing technique to generate the Nsun5$\mathrm{KO}$ mouse as previously described [28]. Two sgRNAs were designed to target exon 3 of the Nsun5 gene (Fig. 1b). The oligos used to generate sgRNA expression plasmids were annealed and cloned into the BsaI sites of pUC57-sgRNA (Addgene 51,132). The genotype was determined by PCR using the genomic DNA obtained from tail biopsies. The Nsun5 deletion in homozygous (-/-) mice was determined by the amplification of $131 \mathrm{bp}$ fragment and the loss of $153 \mathrm{bp}$ fragment (Fig. 1c).

Nsun5 deficiency impairs development of cerebral cortex Nsun5-KO newborn pups were survived and their body weights did not differ significantly from those of wildtype (WT) littermates $(P>0.05, n=12$ mice per experimental group; Fig. 2a). As shown in Fig. 2b, the size of
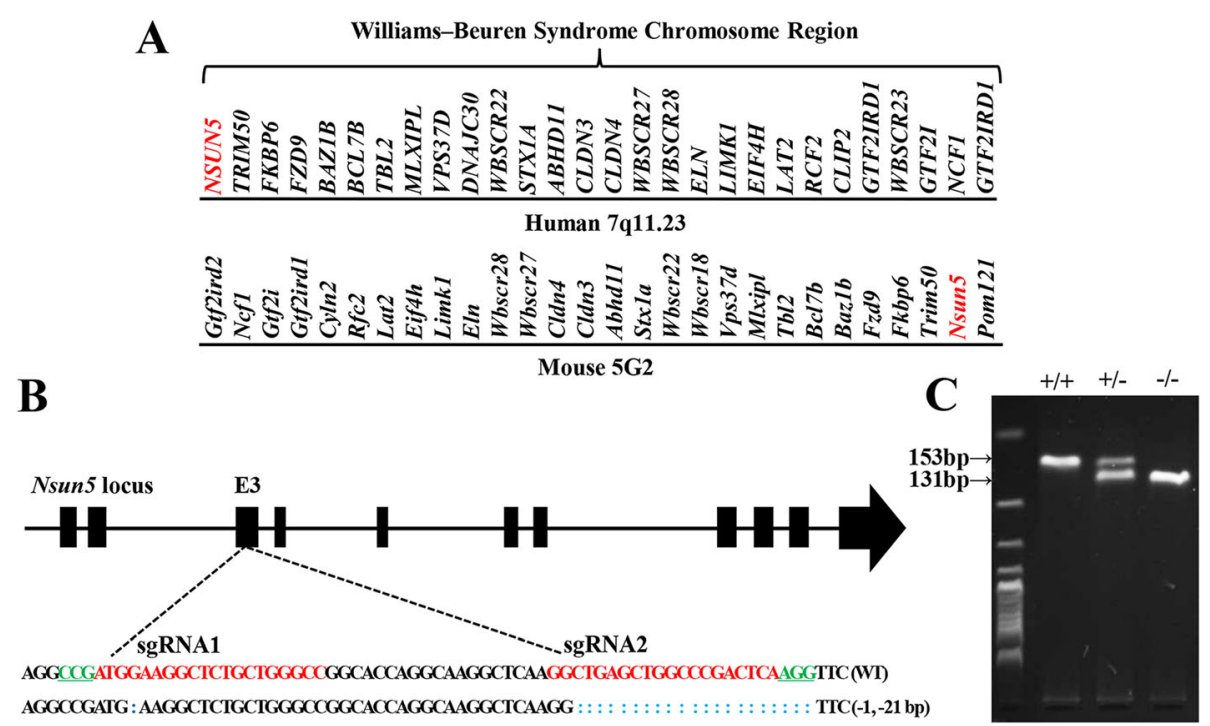

Fig. 1 Construction and genotype verification of Nsun5 null mice. a Comparison of WBS genomic regions in human and mouse. NSUN5 located in human chromosome 7q11.23 (upper) and mouse chromosome 5G2 (bottom). b Two sgRNAs designed to target exon 3 of the Nsun5 gene. c Identification of Nsun5 DNA in WT mice (+/+), heterozygous (+/-) and homozygous (-/-) mice 
A PND10
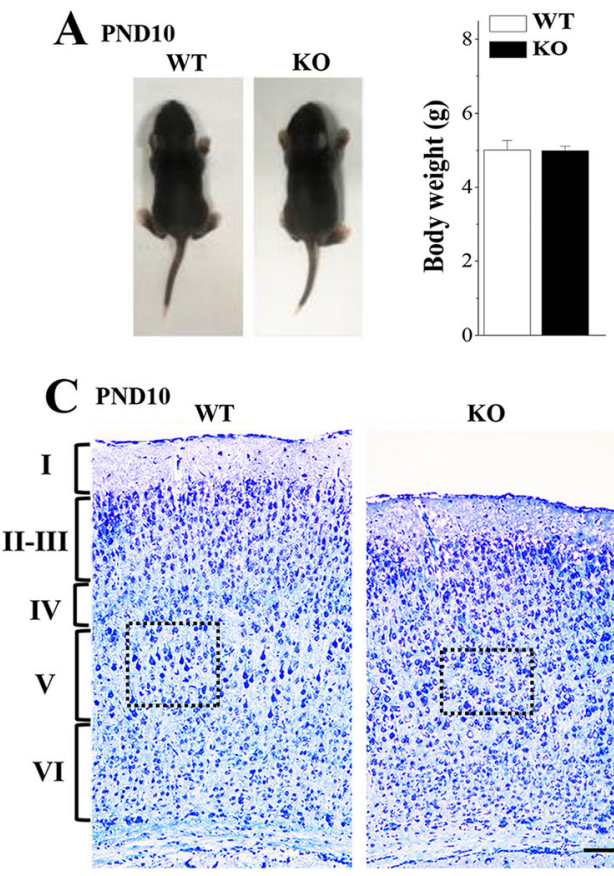

$\mathbf{E}$

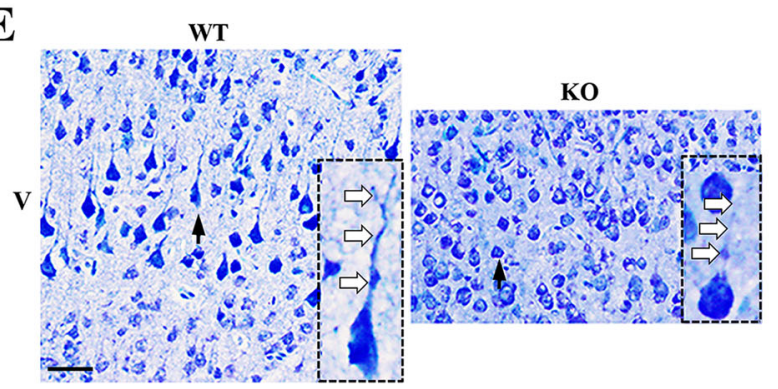

B PND10

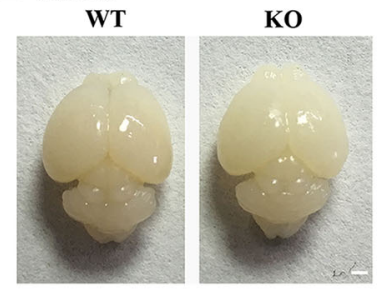

D

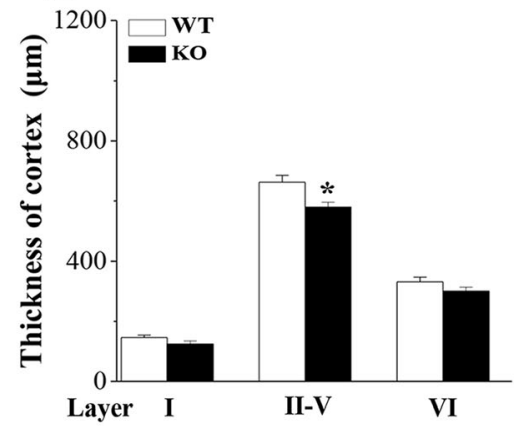

Fig. 2 Nsun5 deficiency impairs development of cerebral cortex. a \& b Body weights and pictures of entire brain of PND10 WT mice (WT) and Nsun5-KO mice (KO). Scale bars, $1 \mathrm{~mm}$. c Representative images of cerebral cortex stained with toluidine blue. Scale bars, $100 \mu \mathrm{m}$. d Bar graph shows the thickness of layers I-VI. ${ }^{*} P<0.05$ vs. WT mice (Student's t test). e Higher power views of the boxed areas in Fig. c. Scale bars, $50 \mu \mathrm{m}$. Representative images of pyramidal cells (arrows) are shown in the bottom right insets. The open arrows indicate the processes and branches of pyramidal cells. Bar graph shows the length of the apical dendrite of pyramidal cells in the layer $\mathrm{V}$. ${ }^{*} P<0.05$ vs. WT mice (Student's $t$ test)

entire brain in postnatal day (PND) 10 Nsun5-KO mice was not obviously different from the age-matched WT mice $(n=6)$. However, the thickness of the cortical plate in Nsun5-KO mice was obviously reduced compared with WT mice $(P<0.05, n=6$, Fig. 2c). It is mainly because of the thinning of layers II-V $(P<0.05, n=6$, Fig. 2d). Notably, the length of the apical dendrite of pyramidal cells in the layer $\mathrm{V}$ of Nsun5-KO mice were finer (Fig. 2e) and shorter than those in WT mice $(P<0.05, n=6)$.

\section{Selective expression of Nsun5 in RGCs of developing cerebral cortex}

To explore the mechanisms underlying Nsun 5 deletionimpaired development of cerebral cortex, we primarily examined the expression of Nsun5 in cerebral cortex of WT mice from E10.5 to PND10 by RT-PCR and
Western blotting ( $n=6$ mice per experimental group). Notably, the levels of the Nsun 5 mRNA (vs. E10.5, $P<$ $0.01, n=6$, Fig. 3a) and Nsun5 protein (vs. E10.5, $P<$ $0.05, n=6$, Fig. $3 \mathrm{~b}$ ) were obviously elevated starting from E12.5. However, the time of Nsun5 protein reaching peak stage had a clear lag in comparison with the level of Nsun 5 mRNA. The highest levels of the Nsun5 mRNA were determined at E12.5 $(P<0.01, n=6)$, while the level of Nsun5 protein reached peak at E14.5 $(P<$ $0.01, n=6$ ), followed by a decrease from E18.5, showing transiently high expression of Nsun 5 in the developing cerebral cortex.

Subsequently, the double immunostaining for Nsun5 with antibodies against Sox 2 or nestin (markers of RGCs), Tbr2 (a marker of IPCs), or Ctip2 and Satb2 (markers of deeper-layer and upper-layer neurons, respectively) were performed to identify the cells expressing 

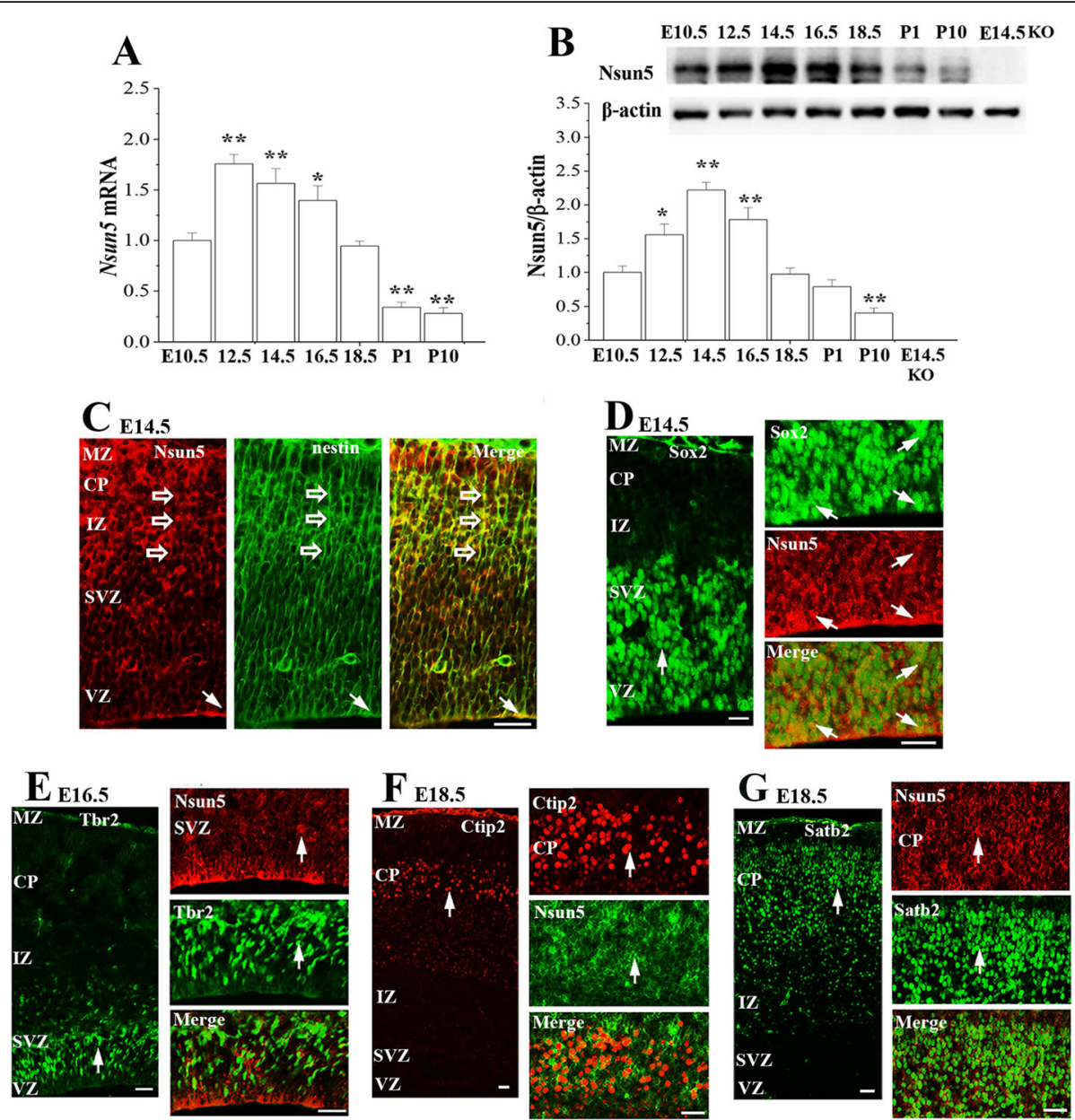

Fig. 3 Dynamic expression of Nsun5 during corticogenesis. a \& b Bar graphs show the levels of cerebral cortex Nsun5 mRNA and Nsun5 protein in E10.5, E12.5, E14.5, E16.5, E18.5, PND1 (P1) and PND10 (P10) WT mice, and E14.5 Nsun5-KO mice (KO). ${ }^{*} P<0.05$ and ${ }^{* *} P<0.01$ vs. E10.5 mice (one-way ANOVA). c Representative images of double immunostaining in cerebral cortices from WT mice for (c) Nsun5 (red) and nestin (green) at E14.5, Scale bars, $25 \mu \mathrm{m}$; d Sox2 (green) and Nsun5 (red) at E14.5, Scale bars, $25 \mu \mathrm{m}$ (views of entire cortex); Scale bars, $25 \mu \mathrm{m}$ (in VZ); e Nsun5 (red) and Tbr2 (green) at E16.5, Scale bars, $25 \mu \mathrm{m}$ (views of entire cortex); Scale bars, $25 \mu \mathrm{m}$ (in SVZ); f Nsun5 (green) and Ctip2 (red) at E18.5, Scale bars, $25 \mu \mathrm{m}$ (views of entire cortex); Scale bars, $25 \mu \mathrm{m}$ (in CP); g Nsun5 (red) and Satb2 (green) at E18.5, Scale bars, $25 \mu \mathrm{m}$ (views of entire cortex); Scale bars, 25 m (in CP). Open arrows represent Nsun5+/nestin+ basal processes of RGC (c); arrows indicate Sox2+ cells (d), Tbr2+ cells (e), Ctip2+ cells (f) and Satb2+ cells (g)

Nsun5. At E14.5, the nestin positive (nestin+) processes extended radially throughout the cerebral wall (Fig. 3c) and overlapped with Nsun 5 immunoreactivity. As shown in Fig. 3d, Sox2 positive (Sox2+) cells in the VZ of cerebral cortex (left panel) expressed the Nsun5 protein (right panel). In contrast, the Nsun 5 protein was not detected in Tbr2 positive (Tbr2+) cells in the SVZ (Fig. 3e). In E18.5 $\mathrm{CP}$, neither the Ctip2 positive (Ctip2+) cells (Fig. 3f) nor the Satb2 positive (Satb2+) cells (Fig. 3g) showed Nsun5 immunoreactivity.

\section{Nsun5 deficiency disrupts growth of radial glial scaffold} Above observations determined that RGCs selectively expressed Nsun5 during developing cerebral cortex. Thus, we examined influence of the Nsun 5 deletion in the development of RGCs and the radial glial scaffolds of RGCs by the immunohistochemistry for nestin, brain lipid binding protein (BLBP) and Sox2. A short apical process anchors the RGC soma at the ventricular surface, while their long basal processes extend to the pial surface $[29,30]$. As shown in Fig. 4a, the nestin+ basal processes radially spanned the entire cerebral cortex in E16.5 and E18.5 WT mice. In contrast, the density of basal processes in Nsun5-KO mice was distinctly reduced, and numerous short basal processes failed to extend perpendicularly and reach the pial basement membrane. The histological differences were readily discernible in Nsun5-KO mice beginning at E14.5, an earlier stage of RGCs scaffold, because the density of BLBP positive (BLBP+) glial scaffolds in E14.5 Nsun5-KO mice 

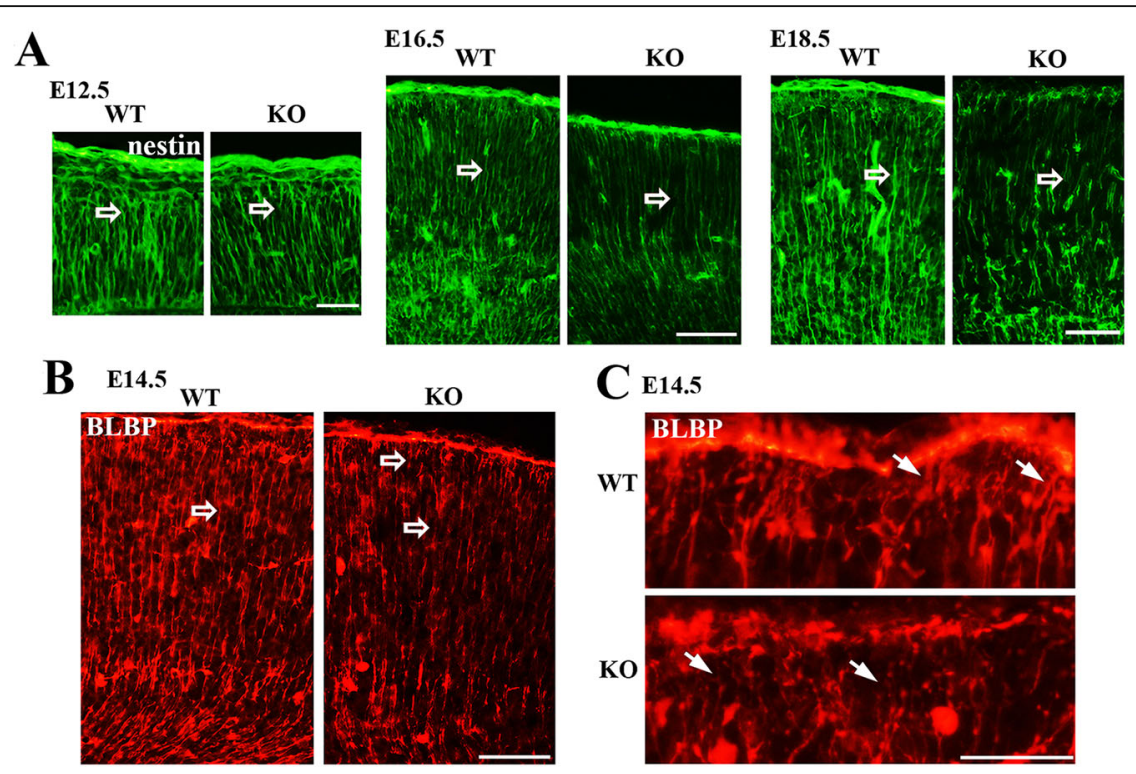

\section{E14.5}
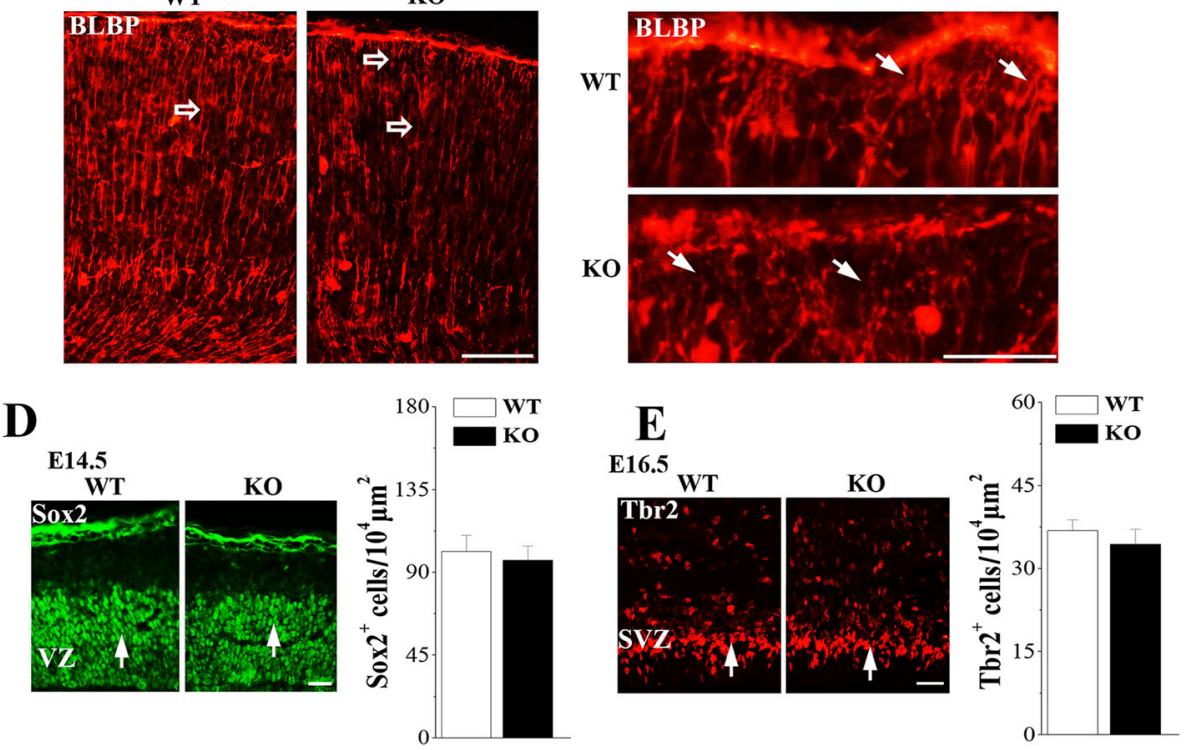

Fig. 4 Nsun5 deficiency disrupts the radial glial scaffolds. a \& b The development of radial glial scaffolds was compared between E12.5-E18.5 WT mice and Nsun5-KO mice. Images of nestin (green) or BLBP (red) immunostaining. Scale bars, $50 \mu \mathrm{m}$ (a); $25 \mu \mathrm{m}$ (b). Many long, parallelly distributed nestin+ or BLBP+ processes span throughout the cortical wall in WT mice. In E14.5-E18.5 Nsun5-KO mice, the radial processes are discontinuous and shorter (open arrows). c High magnification images of BLBP labeling at E14.5. Scale bars, $10 \mu \mathrm{m}$. In WT mice the end-feet of RGC scaffolds attached to the pial BM, but in Nsun5-KO mice many RGC scaffold end-feet detached from the pial BM (arrows). d \& e Representative images of Sox2 at E14.5 or Tbr2 at E16.5. Scale bars, $25 \mu \mathrm{m}$. Bar graphs show the numbers of Sox2+ cells and Tbr2+ cells in WT mice and Nsun5-KO mice

was substantially reduced (Fig. 4b), and the basal processes emanating from the VZ were discontinuous. Moreover, few basal end-feet reached the pial surface to interact with the pial basement membrane in E14.5 Nsun5-KO mice (Fig. 4c). However, the number of Sox2+ cells in E14.5 Nsun5-KO mice was approximately equal to WT mice $(P>0.05, n=6$, Fig. $4 \mathrm{~d})$. In addition, the number of Tbr2+ IPCs within the SVZ was not significantly different between E16.5 WT mice and Nsun5-KO mice ( $P>0.05, n=6$, Fig. 4e).

\section{Nsun5 deficiency impedes the radial migration of cortical neurons}

Next experiment was designed to evaluate whether the disrupted radial glial scaffolds in Nsun5-KO mice affects radial migration of cortical neurons. First, we examined the BrdU positive (BrdU+) cells in the E12.5 cerebral cortex which labels cells of the S-phase. The number of BrdU+ cells in Nsun5-KO mice was approximately equal to WT mice ( $P>0.05, n=6$, Fig. 5a), indicating that the Nsun 5 deficiency failed to alter the proliferation of RGCs. Subsequently, BrdU birth-dating was employed to elucidate the radial migration of cortical neurons [31]. Mice were injected with BrdU at E12.5 or E14.5, respectively, to label deeper-layer neurons (E12.5-E18.5 BrdU+ cells) and upper-layer neurons (E14.5-E18.5 BrdU+ cells) at E18.5 ( $n=6$ mice per experimental group). In comparison with WT mice, the total number of E12.5-E18.5 $\mathrm{BrdU}+$ cells in the cerebral cortex of Nsun5-KO mice was unchanged $(P>0.05, n=6$, Fig. $5 b)$, but the localization of E12.5-E18.5 BrdU+ cells in the deeperlayer was reduced by approximately $16 \%(P<0.05, n=$ $6)$, since more cells were accumulated in the subcortical region $(P<0.01, n=6)$. On the other hand, the total number of E14.5-E18.5 BrdU+ cells in Nsun5-KO mice was less than that in WT mice $(P<0.05, n=6$, Fig. 5 c) . Similarly, the number of E14.5-E18.5 BrdU+ cells in the upper-layers was visibly reduced in Nsun $5-\mathrm{KO}$ 
A
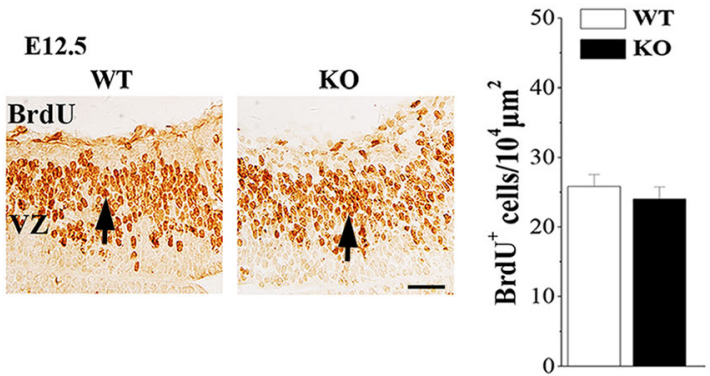

\section{B}
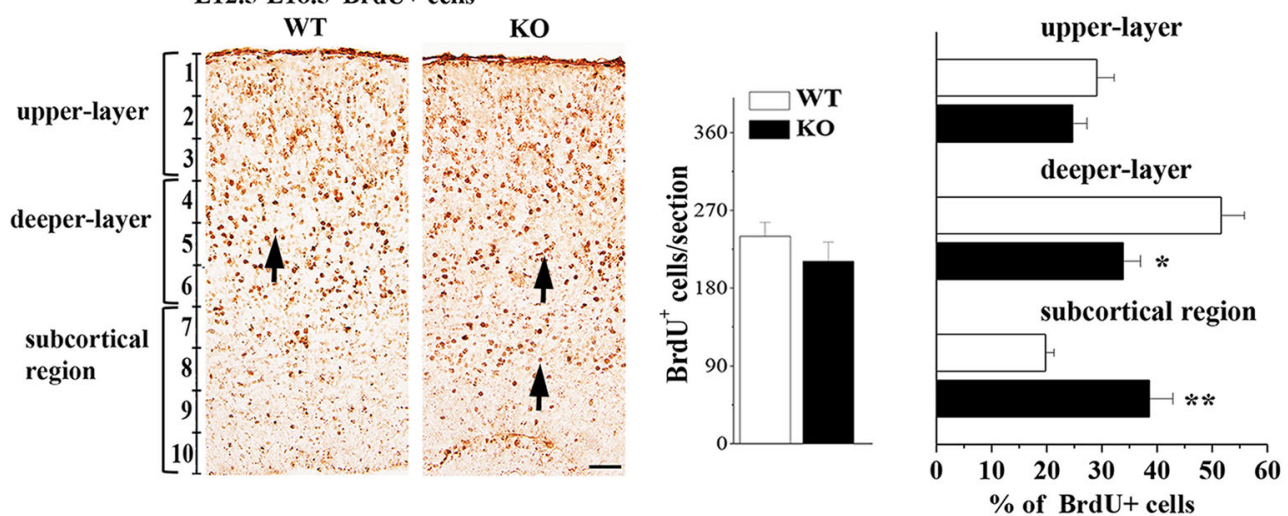

$C_{\text {E14.5-E18.5 BrdU+ cells }}$
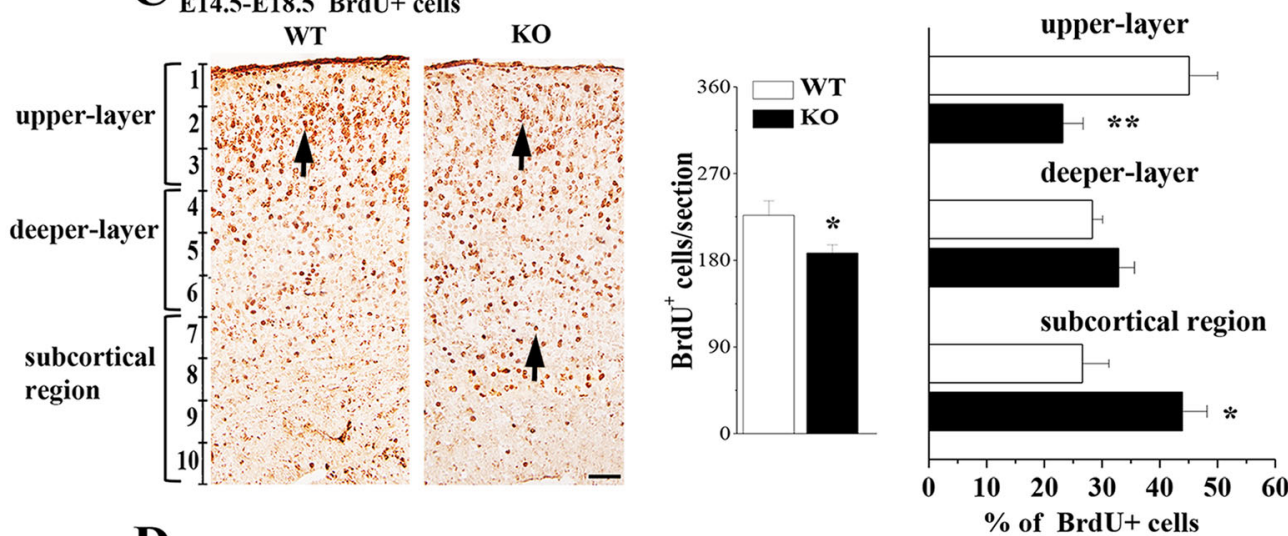

D cleaved caspase-3

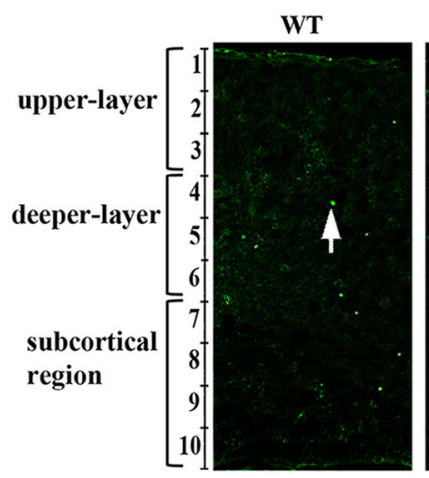

KO
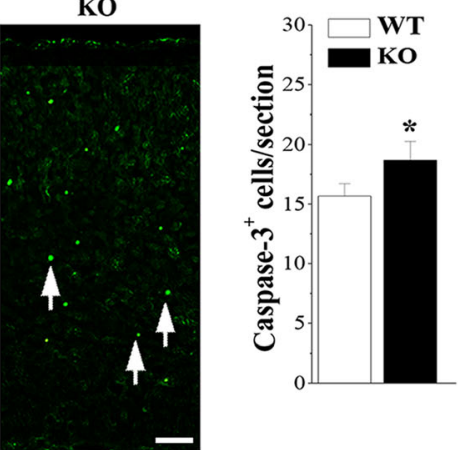

Fig. 5 (See legend on next page.) 
(See figure on previous page.)

Fig. 5 Nsun5 deficiency affects the radial migration of cortical neurons. a Representative images of BrdU immunostaining at E12.5, arrows indicate BrdU+ cells, Scale bars, 25 um. Bar graphs show the numbers of BrdU+ cells. b \& c The cortical distribution of E12.5-E18.5 BrdU+ cells and E14.5-E18.5 BrdU+ cells was compared between WT mice (WT) and Nsun5-KO mice (KO). Representative images of immunostaining for BrdU in E18.5 cerebral cortices. Scale bars, $50 \mu \mathrm{m}$. Bar graphs (in middle column) show the total number of E12.5-E18.5 BrdU+ cells per section (upper panel) and E14.5-E18.5 BrdU+ cells (bottom panel). * $P<0.05$ vs. WT mice. The percentage (\%) of E12.5-E18.5 BrdU+ cells (upper panel) or E14.5E18.5 BrdU+ cells (bottom panel) located in the upper-layers, deeper-layers and subcortical region was showed in the bar graphs (in right column). ${ }^{*} P<0.05$ and ${ }^{*} P<0.01$ vs. WT mice. d Representative images of cleaved caspase-3 immunostaining. Scale bars, $50 \mu \mathrm{m}$. Bar graph shows numbers of caspase-3+ cells (arrows) in E18.5 WT mice and Nsun5-KO mice. ${ }^{*} P<0.05$ vs. WT mice

mice $(P<0.01, n=6)$, which was companied by a subcortical accumulation of E14.5-E18.5 BrdU+ cells $(P<$ $0.05, n=6)$. Using the cleaved caspase-3 immunostaining, we observed an increase in the numbers of cleaved caspase- 3 positive (caspase-3+) cells in the subcortical region of E18.5 Nsun5-KO mice $(P<0.05$, $n=6$, Fig. $5 \mathrm{~d}$ ), indicating the apoptosis of E14.5-E18.5 BrdU+ cells.

\section{Nsun5 deficiency disturbs the laminar location of cortical neurons}

To determine further the effects of the Nsun5 deficiency on the lamination of upper-layer and deeper-layer neurons, layer-specific markers, including the anti-Tbr1 and anti-Ctip2 antibodies that label deeper-layer neurons and the anti-Satb2 antibody that labels upper-layer neurons were used ( $n=6$ mice per experimental group). In
E18.5 WT mice, the majority of Tbr1 positive (Tbr1+) cells (Fig. 6c) and Ctip2 positive (Ctip2+) cells (Fig. 6b) had arrived at the deeper-layers of the CP, and Satb2 positive $($ Satb2+) cells were positioned in the upperlayers of CP (Fig. 6a). In contrast, the deeper-layer neurons and upper-layer neurons in E18.5 Nsun5-KO mice had not migrated into their appropriate lamina and exhibited a disordered distribution in the lower area, mainly in the intermediate zone (IZ). Compared with those in WT mice, the numbers of Tbr1+ cells in cortical layer VI $(P<0.05, n=6)$ and Ctip2+ cells in cortical layer $\mathrm{V}(P<0.01, n=6)$ or the number of Satb2+ cells in cortical layers II/III $(P<0.05, n=6)$ were significantly reduced in Nsun5-KO mice. Although the thickness of total cortical wall in E18.5 Nsun5-KO mice was not significantly altered $(P>0.05, n=6$; Fig. $6 \mathrm{~d})$, the stenosis of the CP was obvious $(P<0.05, n=6)$.
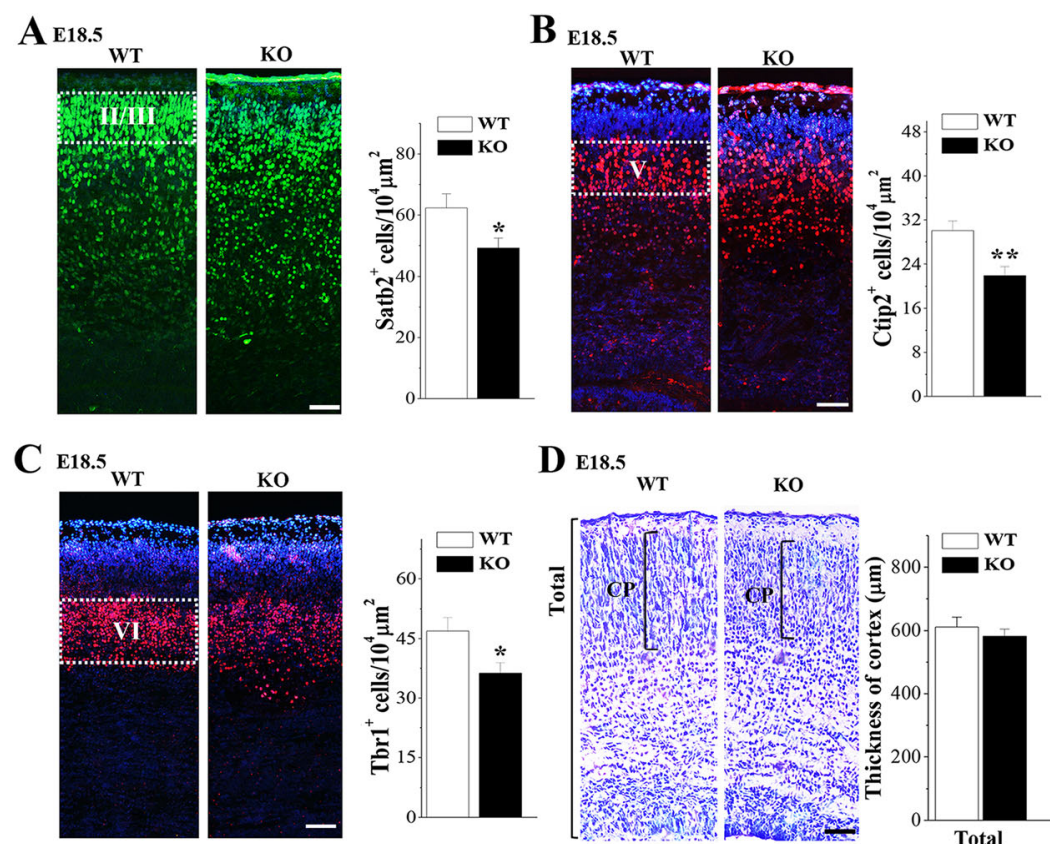

D E18.5

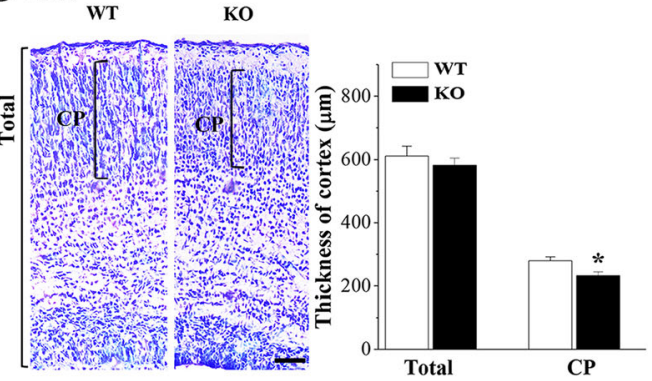

Fig. 6 Nsun5 deficiency affects the laminar organization of cortical neurons. a-c Representative images of immunostaining for Tbr1, Ctip2 with DAPI or Stab2 in E18.5 WT mice (WT) and Nsun5-KO mice (KO). Scale bars, $50 \mu \mathrm{m}$. Bar graphs show the numbers of Tbr1+ cells in layer VI, Ctip2+ cells in layer $V$ and Stab2+ cells in layers II/III. ${ }^{*} P<0.05$ and ${ }^{* *} P<0.01$ vs. WT mice. $\mathbf{d}$ Coronal sections of cerebral cortices stained with toluidine blue in E18.5 WT mice and Nsun5-KO mice. Scale bars, $50 \mu \mathrm{m}$. Bar graph shows the total cortical thickness and CP. ${ }^{*} P<0.05$ vs. WT mice 
Possible mechanisms underlying Nsun5 deletion-impaired glial scaffolds

The development of radial glial scaffold during corticogenesis depends on the dynamic modulation of cytoskeletal and molecular polarity [32]. Polarized expression of cell polarity regulator $\mathrm{Cdc} 42$ and $\mathrm{PKC}$ in RGCs regulates glial end-feet activities and inter-radial glial interactions [33]. In addition, the genetic deletion of the small GTPase RhoA in the developing cerebral cortex results in migration disorders [34]. As shown in Fig. 7a, the Cdc42 protein was mainly located in the radial glial scaffolds of RGCs and overlapped perfectly with Nsun5 in cerebral cortex of E14.5 WT mice. Notably, the immunoreaction of Cdc42 in E14.5 Nsun5-KO mice was weaker than that in WT mice (Fig. 7b). Moreover, western blot analysis showed that the level of Cdc42 protein in Nsun5-KO mice was reduced compared to WT mice $(P<0.01, n=6$, Fig. $7 \mathrm{~d})$. However, the level of $C d c 42$ mRNA was unchanged in Nsun5-KO mice $(P>0.05$, $n=6$; Fig. 7c). In contrast, neither the levels of RhoA, PKC $\zeta$ and Akt protein $(P>0.05, n=6)$ nor the levels of $R h o A, P K C \zeta$ and $A k t$ mRNA $(P>0.05, n=6)$ were altered in Nsun5-KO mice. In addition, Nsun5-KO mice did not show the changes in the levels of PKCद $(P>0.05, n=6$, Fig. 7e) and Akt expression or phosphorylation $(P>0.05, n=6$, Fig. 7f). The appropriate regulation of GSK3 $\beta$ is required to maintain the overall polarity of the radial glial scaffold [33]. However, the levels of phospho-GSK3 $\beta$ at Tyr216 $(P>0.05, n=6$, Fig. $7 \mathrm{~g})$ and at Ser9 $(P>0.05, n=6)$ failed to be altered in Nsun5-KO mice.

\section{Discussion}

The Nsun5 protein was selectively expressed in radial glial cells during embryonic cortex. The single-gene Nsun5 knockout in mice disrupted the growth of radial glial scaffolds during corticogenesis to impede the radial migration of neocortical neurons, resulting in confused
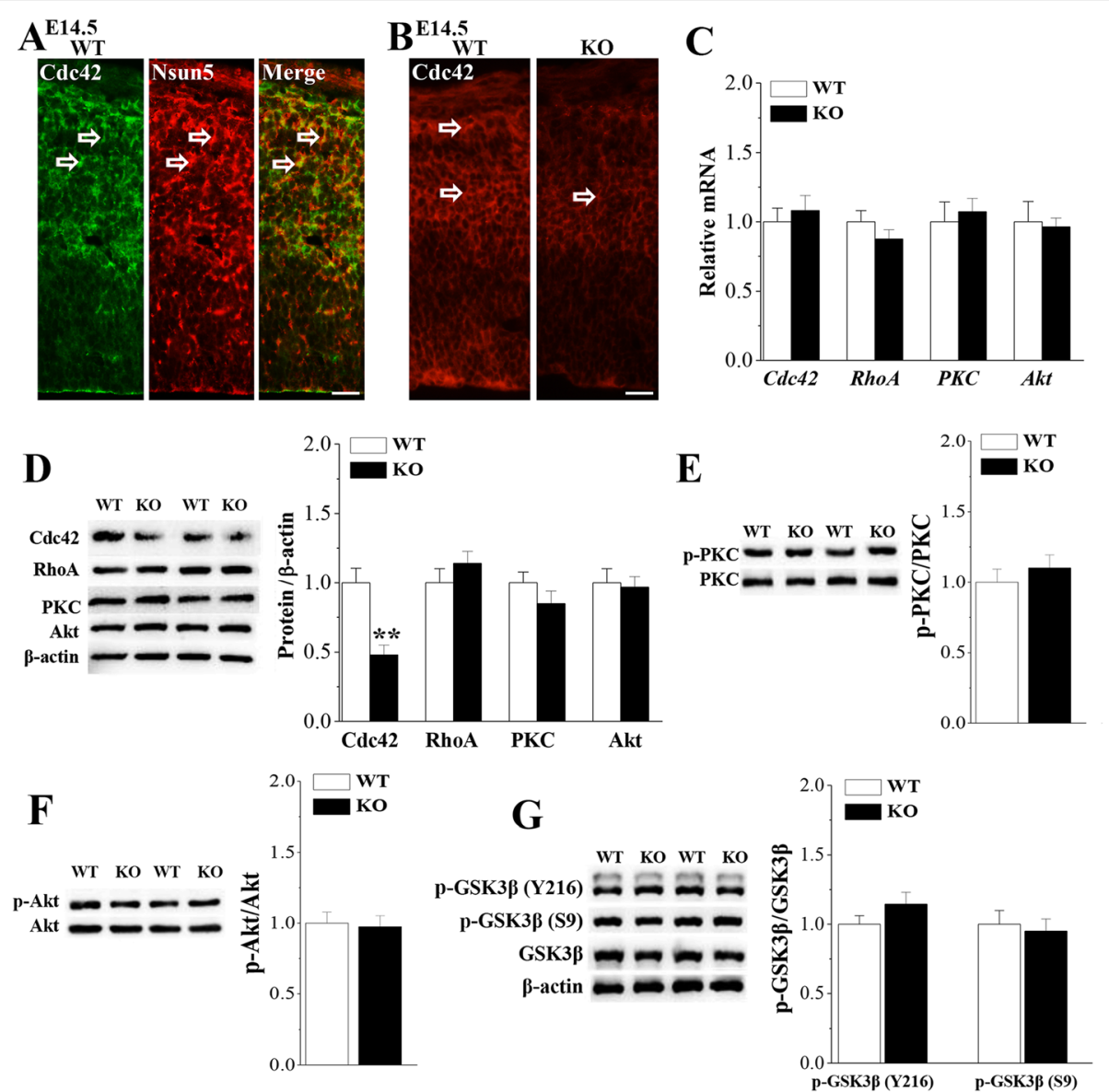

Fig. 7 Nsun5 deficiency reduces the Cdc42 expression. a Representative images of double immunostaining for Cdc42 (green) and Nsun5 (red) in E14.5 WT mice (WT). Scale bars, $50 \mu \mathrm{m}$. b Representative images of Cdc42 immunoreactivity (open arrows) in E14.5 WT mice (WT) and Nsun5-KO mice (KO). Scale bars, $50 \mu \mathrm{m}$. c Levels of Cdc42, RhoA, PKC and Akt mRNA. $\mathbf{d}$ Levels of Cdc42, RhoA, PKC and Akt protein in cerebral cortex of WT mice and Nsun5-KO mice. ${ }^{*} P<0.01$ vs. WT mice. e-g Levels of PKC (p-PKC), Akt (p-Akt), GSK3 $\beta$ at Y216 (p-GSK3 $\left.3-Y 216\right)$ and GSK3 $\beta$ at S9 (p-GSK3ß-S9) phosphorylation 
positioning of upper-layer and deeper-layer neurons and the morphological abnormalities in pyramidal neurons. Nsun5 is heterozygous in patients WBS. Not only Nsun5 knockout homozygous but also heterozygous deletion of Nsun5 in mice (Nsun5+/- mice) caused the phenotype of spatial cognitive defects [13]. Similarly, we in the present study observed that the thickness of the cortical plate in Nsun $5+/-$ mice (Additional file 1: Figure S1A\&B) and the apical dendrite of pyramidal cells in the layer V of Nsun5+/- mice were less than those in WT mice (Additional file 1: Figure S1C). The findings in the present study provided the first in vivo evidence that the transiently high expression of Nsun 5 during corticogenesis is essential for the development of cerebral cortex.

In the embryonic neocortex, the Nsun5 protein was expressed at relatively high levels as early as E12.5, reached peak levels at E14.5. The Nsun5 protein in E14.5 neocortex was identified in the bodies of Sox2+ RGCs and processes of nestin+ RGCs Moreover, we observed the co-localization the Nsun5 protein and the cell polarity regulator $\mathrm{Cdc} 42$ in the $\mathrm{CP}$ and $\mathrm{MZ}$ of E14.5 neocortex. The thickness of the VZ, which reflects the size of the RGC pool, increases from E11.5 to E13.5, stays unchanged at E13.5-E14.5, and decreases from E14.5 to E16.5 [35]. The loss of Nsun5 has been reported to reduce the replicative lifespan of yeast mother cells [20]. Our results indicate that the deletion of Nsun5 in developing cerebral cortex likely does not affect the proliferation of RGC, since the number of BrdU+ cells in the VZ of E12.5 Nsun5-KO mice was not changed. An earlier study [36] reported that the loss of Cdc42 resulted in the gradual conversion of apical VZ progenitors to basal SVZ progenitors, indicating that Cdc42 is crucial for the maintenance of VZ progenitors. The Cdc42 deletion is reported to cause a displacement of RGCs within the proliferative niche [33]. Although the expression level of Cdc42 was reduced in the cerebral cortex of E14.5 Nsun5-KO mice, the number of Sox2+ RGCs and Tbr2+ IPCs in the VZ did not differ significantly from WT mice.

Layer formation in the developing cerebral cortex requires the movement of neurons from their site of origin to their final laminar position. The early-born neurons occupy the deep layers, while later-generated cortical plate cells migrate past deeper-layer neurons and settle in more superficial layers. Several studies have confirmed that the RGCs, which reside in the VZ and extend a fibre to the pial surface [29], serve as guides along which the neurons migrate to reach the correct lamina of the cortical plate, where they will become pyramidal cells in the adult cortex $[37,38]$. Although the number of RGCs was unchanged in Nsun5-KO mice, the basal radial processes were distinctly reduced at E14.5-E18.5.
Furthermore, the basal processes in Nsun5-KO mice were truncated, and did not extend perpendicularly to the pial surface. Thus, it is indicated that the impaired radial glial scaffolds in Nsun5-KO mice failed to provide guidance for migration of cortical neurons. Indeed, the idea is supported by the experimental results that the upper-layer and deeper-layer cortical neurons did not migrate into the appropriate lamina and arrested just below the cortical plate in E18.5 Nsun5-KO mice, resulting in the thinning of layers II-V in the cerebral cortex of PND10 Nsun5-KO mice. Two general modes of migration have previously been defined in the developing cerebral cortex: locomotion and nuclear translocation. The radial glia-guided locomotion involves the movement of the entire cell. During nuclear translocation, the cell first extends a leading process in the direction of migration, and then moves the nucleus to reach destination. The upper-layer cortical neurons migrate by radial glia-guided locomotion [39], whereas the deeper-layer cortical neurons migrate by a radial glia-independent manner [40]. Nadarajah et al. have demonstrated that locomotion and nuclear translocation are not cell-type specific and are responsible for the radial migration of cortical neurons. Although at early ages some cells may move by translocation only, locomoting cells also translocate once their leading process reaches the marginal zone $[41,42]$.

The final laminar positioning of cortical neurons is coregulated by cell type- and layer-specific transcription factors that play concomitant roles in determining the molecular identity and axonal connectivity of these neurons. In the developing neocortex, disrupted neuronal migration affects the net forward extension of their axons, leading to a termination of axonal growth [43]. Indeed, we observed considerable deficits in the axonal growth and branching of pyramidal cells in postnatal cerebral cortex of Nsun5-KO mice. Importantly, the number of upper-layer neurons (E14.5-E18.5 BrdU+ cells) was reduced in Nsun5-KO mice. The RGCs, as a source of neurons and IPCs, is a key step in determining overall neuronal production [44]. The number of Tbr2+ IPCs in the SVZ of Nsun5-KO mice was not reduced, indicating that the reduction of upper-layer neurons is unlikely due to deficit in the neuronal production of RGCs. In the neocortex of Nsun5-KO mice, we observed an obvious increase in the number of apoptotic cells. The findings would help explain the possible mechanisms underlying Nsun 5 deletion-impaired development of cerebral cortex: the Nsun5 deficiency in RGCs disrupts the growth of radial glial scaffolds; the radial migration of cortical neurons does not progress smoothly from the ventricles to the cortical plate, resulting in an abnormal laminar organization that affects the development of pyramidal cells and causes neuronal 
death. The pre-mature loss of cortical neurons in the embryonic cortex can produce a smaller neocortex. The Nsun5 deficiency caused the thinning of the cortical plate, whereas the total cortical thickness or the size of entire brain in Nsun5-KO mice did not exhibit obvious reduction in comparison with WT mice. A possible reason might be an expansion of the subcortical region in Nsun5-KO mice. Accumulating evidence suggests that loss-of-function mutations in genes encoding cytoskeletal regulators can cause the subcortical accumulation of multipolar cells since the neuronal migration are impaired, leading to the malformation periventricular heterotopias $[43,45,46]$. The genetic deletion of the doublecortin gene in mice causes the pre-mature termination of migration of many neurons to form subcortical heterotopias within the IZ [46].

The function of radial glia during corticogenesis depends on the dynamic modulation of cytoskeletal and molecular polarity [32, 47]. Cdc42 localizes to dynamically active regions of radial glia in the developing cerebral cortex. Disruption of Cdc42 activity altered polarized growth of radial glial cells, radial glial end-feet activities and inter-radial glial interactions [33]. Cdc42 is required to maintain the apico-basal polarity and adherens junctions $[36,48]$. A critical finding in the present study is that the Cdc42 protein in Nsun5-KO mice was reduced, which affects the growth and function of radial glial scaffold. The conditional inactivation of GSK3 $\beta$ in radial progenitors has been reported to disrupt the growth of radial processes and the migration and placement of neurons [33]. Nsun5-KO mice did not show the changes in the expression and phosphorylation of GSK3 $\beta$. Nsun5 is known to be a static molecular machine executing translation, the ribosome exhibits functional diversity by modifying a single rRNA nucleotide, resulting in an alteration of rRNA-mediated translational regulation [20]. It is proposed that the Nsun5dependent methylation of rRNA is important for a regulation of ribosomal function. Many mRNAs have short upstream open reading frames within their 5'UTRs, which are known to modulate gene expression at the translational level $[49,50]$. The decrease in the Cdc42 protein in Nsun5-KO mice was not associated with changes in the level of $C d c 42$ mRNA. Thus, the Nsun5 deficiency is highly likely to affect the Cdc42 expression at the translational level. Certainly, study of the molecular mechanisms underlying the Nsun5 deficiencyreduced translation of $\mathrm{Cdc} 42$ should be an interesting subject for future work.

The Nsun5 protein is selectively expressed in RGCs at embryonic stages. The results obtained from Nsun5-KO mice will bring new insights into the critical role of the RNA methyltransferase Nsun 5 in the development of the cerebral cortex. Although much more work needs to be performed, the Nsun5 deficiency might be a major contributing factor to the neuro-developmental phenotype of WBS, which might be associated with the cognitive behavioral profile of WBS patients.

\section{Materials and methods \\ Generation and identification of Nsun5 null mice}

The procedures involving animals and their care were conducted in accordance with the ARRIVE guidelines of Laboratory Animal Care [51]. All animal experiments were approved by the Institutional Animal Care and Ethical Committee of the Nanjing Medical University (No. 2014-153) and were performed in accordance with the guidelines of the Laboratory Animal Research Institute for Experimental Animals of Nanjing Medical University. All efforts were made to minimize animal suffering and to reduce the number of animals used. The mice were maintained under constant environmental conditions (temperature of $23 \pm 2{ }^{\circ} \mathrm{C}$, humidity of $55 \pm 5 \%$, and a 12:12-h light/dark cycle) in the Animal Research Center of Nanjing Medical University with free access to food and water. The Nsun5-KO mouse was generated by CRISPR/Cas9 genome editing. The oligos used to generate sgRNA expression plasmids were annealed and cloned into the Bsal sites of pUC57sgRNA (Addgene 51,132) as previously described [28]. The following oligo sequences are used: sgRNA1-sense: TAGGCCCAGCAGAGCCTTCCAT; sgRNA1-antisense: AAACatggaaggctctgctggg; sgRNA2-sense: TAGGctgagctggcccgactca; and sgRNA2-anntisense: AAACTG AGTCGGGCCAGCTCAG. Founder mice were backcrossed onto the C57BL/6 J background. Homologous Nsun5 (Nsun5-/-) mice (hereafter referred to as Nsun5$\mathrm{KO}$ mice) were then obtained by mating heterozygous Nsun5 (Nsun5+/-) mice.

\section{Experimental design}

The morning of vaginal plug detection was designated embryonic day (E) 0.5 and the day of birth was considered postnatal day (PND) 0. The mice from E10.5 to PND10 were randomly divided into 5 experimental groups. First, we observed the cortical thickness and laminar organization, and the morphological alteration of the pyramidal neurons in PND10 Nsun5-KO mice. Subsequently, we determined the dynamic expression of Nsun5 and the distribution of Nsun5 positive (Nsun5+) cells in developing cerebral cortex from E10.5 to PND10. After the characteristics of Nsun5+ cells were identified, we investigated the effects of Nsun5 deficiency on growth of radial glial scaffold, proliferation, differentiation and transformation of RGCs. We further examined the influence of Nsun5 deficiency on radial migration and laminar location of cortical neurons in the development of cerebral cortex. Finally, we explored 
the mechanisms underlying Nsun5-regulated growth of radial glial scaffold.

\section{Antibodies}

The following commercially available antibodies were used: Rabbit anti-Nsun5 (15449-1-AP, Proteintech Group Inc., China; Western blot/1:300, IF/1:100), rabbit antiCdc42 (2466, Cell Signaling Technology Inc., Boston, MA, USA; 1:1000), rabbit anti-phosphorylated glycogen synthase kinase 3 $\beta$ (p-GSK3 $\beta$, Ser9, 9322, Cell Signaling Technology; 1:1000), rabbit anti-phosphorylated GSK3 $\beta$ (Tyr216, sc-11,758, Santa Cruz Biotechnology Inc.; 1: 1000), rabbit anti-GSK3 $\beta$ (ab32391, Abcam, Cambridge, United Kingdom; 1:1000), rabbit anti-RhoA (10749-1-AP, Proteintech Group; 1:1000), rabbit anti-Akt (4691, Cell Signaling Technology; 1:1000), rabbit anti-phosphorylated Akt (4060, Cell Signaling Technology; 1:1000), rabbit antiPKCל (9368, Cell Signaling Technology; 1:1000), rabbit anti-phosphorylated PKC (9378, Cell Signaling Technology; $1: 1000)$, mouse anti- $\beta$-actin (3700, Cell Signaling Technology; 1:1000), mouse anti-BrdU antibody (MAB4072, Millipore, Billerica, MA, USA; 1:1000), mouse anti-nestin (Rat-401, Developmental Studies Hybridoma Bank; 1:150), rabbit anti-BLBP (ab32423, Abcam; 1:1000), mouse anti-Sox2 (sc-365,823, Santa Cruz Biotechnology; 1:100), rat anti-Ctip2 (ab18465, Abcam; 1:500), rabbit anti-Tbr1 (ab31940, Abcam; 1:1000), mouse anti-Satb2 (ab51502, Abcam; 1:200), rabbit anti-cleaved caspase-3 (ab2302, Abcam; 1:300), rabbit anti-Tbr2 (ab23345, Abcam; 1:500) or chicken anti-Tbr2 (AB15894, Millipore; 1:1000). The secondary antibodies conjugated with Alexa fluorophores 488 or 555 (Invitrogen; 1:500) and the biotinylated goat anti-mouse secondary antibody (Santa cruz biotechnology; 1:200) were directed against the IgGs of the primary antibody species.

\section{Immunohistochemistry examination}

Mice older than E12.5 were deeply anesthetized with isoflurane and perfused with cold 0.1 M PBS followed by $4 \%$ paraformaldehyde (PFA) for $6 \mathrm{~h}$ at $4{ }^{\circ} \mathrm{C}$ and transferred into $30 \%$ sucrose solution for cryoprotection. The coronal sections were cut at 10 or $70 \mu \mathrm{m}$, respectively, using a freezing microtome (Leica, Nussloch, Germany). The sections were mounted on gelatin-coated slides and allowed to dry over-night at room temperature.

\section{Toluidine blue staining and Nissl staining}

After gradient dehydration, the $10 \mu \mathrm{m}$ sections were performed the toluidine blue staining and the $70 \mu \mathrm{m} \mathrm{sec}$ tions were stained with Nissl solution using standard protocols [52].

\section{Immunofluorescence staining}

Twelve histological sections per mouse were used for immunostaining of each antibody. The immunofluorescence staining was performed as previously described [53]. The sections were blocked with $1 \%$ bovine serum albumin (BSA) for $60 \mathrm{~min}$ at $4{ }^{\circ} \mathrm{C}$ and incubated with the primary antibodies against Nsun5, nestin, BLBP, Sox2, Ctip2, Tbr1, Satb2, Tbr2, cleaved caspase-3 or Cdc42 overnight at $4{ }^{\circ} \mathrm{C}$. For double immunofluorescence staining, sections were incubated with two primary antibodies: Nsun 5 and Sox2, Nsun 5 and nestin, Nsun 5 and Ctip2, Nsun5 and Satb2, Nsun5 and Cdc42. After washing, sections were incubated with the appropriate secondary antibodies for $2 \mathrm{~h}$ at room temperature. Sections were incubated with DAPI (Sigma) for $5 \mathrm{~min}$.

\section{BrdU immunostaining and birth-dating experiments}

The thymidine analogue BrdU (Sigma-Aldrich, St. Louis, $\mathrm{MO})$ was intraperitoneally injected into pregnant females at a concentration of $50 \mathrm{mg} / \mathrm{kg}$ body weight. For acute BrdU labeling at E12.5, embryonic brains were harvested $30 \mathrm{~min}$ after a single injection of BrdU. For birth-dating experiments, BrdU was injection at E12.5 or E14.5, and then brains were fixed with 4\% PFA at E18.5 mice to examine E12.5-E18.5 BrdU+ cells (deeper-layer neurons) and E14.5-E18.5 BrdU+ cells (upper-layer neurons) as previously described [31]. The coronal sections $(10 \mu \mathrm{m})$ were acid-treated with $2 \mathrm{M} \mathrm{HCl}$ for $30 \mathrm{~min}$ at $37^{\circ} \mathrm{C}$, and then incubated in primary antibody of antiBrdU overnight at $4{ }^{\circ} \mathrm{C}$. Immunoreactivities were visualized with avidin-biotin horseradish peroxidase complex (ABC Elite; Vector Laboratories, Inc., Burlingame, CA, USA) using 3,3'-diaminobenzidine as chromogen.

\section{Morphometric analysis and statistics}

(1) Images of Nissl staining were obtained on a conventional light microscope (Olympus DP70, Tokyo, Japan) by a stereological system, consisting of a CCD camera (Olympus DP70), a motorized specimen stage for automatic sampling, and a computer running Microbrightfield Stereo Investigator software (MicroBrightField, Williston, USA). Layers I, II/III, V, and VI were discriminated using multiple criteria. Layer VI was clearly distinguishable from layer $\mathrm{V}$ based on the cell orientations. In layer $\mathrm{V}$, most pyramidal cells were oriented perpendicular to the pial surface and the external capsule. Layer II/ III pyramidal cells had a short apical dendrite and extensive basilar dendrites. In contrast, layer V pyramidal cells had a long apical dendrite and less extensive basilar dendrites. Z-stack images were taken in the cortex at $40 \times$. We used the Neurolucida Neuron Tracing Software to trace the apical dendrite of layer V pyramidal cells [54] to measure the length of the apical dendrite. Image analysis was completed through ImageJ software. (2) Images 
of immunofluorescence staining were captured using a fluorescence microscope (Olympus DP70, Tokyo, Japan). At least six embryos were analyzed for each experimental group of morphometric analysis. Ten matching sections from both hemispheres of each brain were used for the measurements and comparisons. The Sox $2+$ cells, Tbr2+ cells and cleaved caspase-3+ cells in each radial segment were $200 \mu \mathrm{m}$ in width and spanned from the ventricular surface to the pia [30] were counted using the manual tag function of Image Pro-Plus 6 (Media Cybernetics) by an experimenter who was blinded to the mouse genotype. (3) For the cell proliferation assay, the number of BrdU+ cells in each radial unit was counted [31]. (4) For the radial migration analysis of neurons, the distribution of E12.5-E18.5 BrdU+ cells (deeper-layer neurons) and E14.5-E18.5 BrdU+ cells (upper-layer neurons) was analyzed in the different compartments of the cortex. The cortex was divided into ten bins of with $300 \mu \mathrm{m}$ in width. Subsequently, bins $1-3,4-6$ and 7-10 were again grouped as upper-layer, deeper-layer (middle region) and subcortical region (bottom region), respectively. The percentage of BrdU+ cells in each layer was determined, and results were plotted as histograms.

\section{Western blot analysis}

The cerebral cortices were homogenized in $200 \mu \mathrm{l}$ of Tris buffer (pH 7.4) containing 10\% sucrose, phosphatase inhibitors and protease inhibitors (Complete; Roche Diagnostics), sonicated and stored at $-80^{\circ} \mathrm{C}$ until use. Protein concentrations were quantified using the $\mathrm{BCA}$ assay (Pierce). Equal amounts of protein were separated by SDS-polyacrylamide gel electrophoresis and transferred to PVDF membranes. Membranes were blocked with 5\% non-fat milk in Trisbuffered saline (TBS)/Tween-20 and then incubated with antibodies against Nsun5, Cdc42, RhoA, p-Akt, p-PKC or pGSK3 $\beta$ (Ser9 or Tyr216) at $4{ }^{\circ} \mathrm{C}$ for $24 \mathrm{~h}$. Appropriate HRPconjugated secondary antibodies were incubated with the membranes for $1 \mathrm{~h}$ at room temperature and signals were visualized using an enhanced chemiluminescence detection kit (ECL, Millipore). Following visualization, the blots were stripped with stripping buffer for $15 \mathrm{~min}$ and then incubated with antibodies against Akt, PKC, GSK3 $\beta$ or $\beta$-actin at $4{ }^{\circ} \mathrm{C}$ for $24 \mathrm{~h}$. Western blot bands were scanned and analyzed using the ImageJ software package (NIH).

\section{Reverse transcription-polymerase chain reaction (RT-PCR)}

Embryos were moved from pregnant females that had been anesthetized with $\mathrm{CO}_{2}$ and placed on ice. The dorsal cerebral cortices (E14.5-PND10) were dissected, or the total telencephalon was removed (E10.5-E12.5). The tissue was immediately transferred to Trizol reagent (Invitrogen, Camarillo, CA) and processed for total RNA isolation according to the manufacturer's protocol. Then, the total RNA was reverse-transcribed into cDNAs using a Prime Script RT reagent kit (Takara, Japan) for quantitative PCR (ABI Step
Table 1 Primers for quantitative real-time PCR

\begin{tabular}{lll}
\hline & Forward & Reverse \\
\hline Nsun5 & GAGGGAAGGGTGGATAAGG & GGCACGATGCGGATGTAG \\
Cdc42 & GTTGGTGATGGTGCTGTTG & CTGTGGATAACTTAGCGGTCG \\
RhoA & CATTGACAGCCCTGATAGTT & TCGTCATTCCGAAGGTCCTT \\
PKC & ACCCTCGTAGAGAAGCGTGT & TGAAAGTGGAGTGAAGCTG \\
GAPDH & TGGGTGTGAACCACGAG & ACCACAGTCCATGCCATCAC \\
\hline
\end{tabular}

One Plus, Foster City, CA) in the presence of a fluorescent dye (SYBR Green I; Takara). The relative expression of genes was determined using the 2- $\Delta \Delta \mathrm{ct}$ method with normalization to GAPDH expression. The primers for RTPCR were designed based on published mouse gene sequences. The primers for Nsun5, Cdc42, RhoA, PKC, Akt and GAPDH are listed in Table $1[29,31,55]$.

\section{Statistical analyses}

Data were retrieved and processed using MicroCal Origin 9.2 software (Origin Lab, Northampton, MA, USA). Group data are presented as means \pm standard errors of the means (SEM). All statistical analyses were performed using SPSS software, version 18.0 (SPSS Inc., Chicago, IL, USA). Differences between means were analyzed using one way Analysis of Variance (ANOVA) and Student's $t$ test. ${ }^{*} P<0.05$, $* P<0.01$.

\section{Additional file}

Additional file 1: Figure S1. Nsun5 deficiency impairs development of cerebral cortex. A Representative images of cerebral cortex stained with toluidine blue in WT mice and heterozygous deletion of Nsun5

(Nsun5+/-) mice. Scale bars, $100 \mu \mathrm{m}$. B Bar graph shows the thickness of layers I-VI. ${ }^{*} P<0.05$ vs. WT mice (Student's t test). $\mathbf{C}$ Higher power views of the boxed areas in the layer $V$. Scale bars, $50 \mu \mathrm{m}$. Representative images of pyramidal cells (arrows) are shown in the bottom right insets. The open arrows indicate the apical dendrite of pyramidal cells. Bar graph shows the length of the apical dendrite in WT mice and Nsun5+/mice. ${ }^{*} P<0.05$ vs. WT mice (Student's t test). (DOC $2565 \mathrm{~kb}$ )

\section{Abbreviations}

BLBP: Brain lipid binding protein; BM: Basement membrane; BSA: Bovine serum albumin; DCX: Doublecortin; IPC: Intermediate progenitor cell; IZ: Intermediate zone; PND: Postnatal day; RGC: Radial glial cell; SVZ: Subventricular zone; VZ: Ventricular zone; WBS: Williams-Beuren syndrome

\section{Acknowledgements}

We thank Dr. Rui Liu, Department of Neurobiology, Nanjing Medical University for his technical assistance.

\section{Authors' contributions}

$C P$ performed the immunostaining experiments and the western blotting experiments. ZT performed the RT-PCR analysis. YZ carried out the animal care. $C L$ and SB designed the experiments and prepared the manuscript. All authors read and approved the final manuscript.

\section{Funding}

This work was supported by National Natural Science Foundation of China (grant numbers 81671253; 81471157), Jiangsu Provincial Natural Science Foundation of China (grant number BE2016765), National 973 Basic Research Program of China (grant number 2014CB943303). 


\section{Availability of data and materials}

All data generated or analyzed during this study are included in this published article.

\section{Ethics approval and consent to participate}

The procedures involving animals and their care were conducted in accordance with the ARRIVE guidelines of Laboratory Animal Care. All animal experiments were approved by the Institutional Animal Care and Ethical Committee of the Nanjing Medical University (No. 2014-153).

\section{Consent for publication}

Not applicable.

\section{Competing interests}

The authors declare that they have no competing interests.

\section{Author details}

${ }^{1}$ State Key Laboratory of Reproductive Medicine, Nanjing Medical University, Tianyuan East Road 818, Nanjing, China. ²Department of Physiology, Nanjing Medical University, Tianyuan East Road 818, Nanjing, China.

Received: 12 June 2019 Accepted: 21 August 2019

Published online: 28 August 2019

\section{References}

1. Ewart AK, Morris CA, Atkinson D, Jin W, Sternes K, Spallone P, et al. Hemizygosity at the elastin locus in a developmental disorder, Williams syndrome. Nat Genet. 1993;5(1):11-6.

2. Pober BR. Williams-Beuren syndrome. N Engl J Med. 2010;362(3):239-52.

3. Mila M, Carrio A, Sanchez A, Gomez D, Jimenez D, Estivill X, et al. Clinical characterization, molecular and FISH studies in 80 patients with clinical suspicion of Williams-Beuren syndrome. Med Clin (Barc). 1999;113(2):46-9.

4. Mervis CB, Robinson BF, Bertrand J, Morris CA, Klein-Tasman BP, Armstrong SC. The Williams syndrome cognitive profile. Brain Cogn. 2000;44(3):604-28.

5. Meyer-Lindenberg A, Mervis CB, Berman KF. Neural mechanisms in Williams syndrome: a unique window to genetic influences on cognition and behaviour. Nat Rev Neurosci. 2006;7(5):380-93.

6. Bellugi U, Lichtenberger L, Jones W, Lai Z, St George MI. The neurocognitive profile of Williams Syndrome: a complex pattern of strengths and weaknesses. J Cogn Neurosci. 2000;12(Suppl 1):7-29.

7. Borralleras C, Mato S, Amedee T, Matute C, Mulle C, Perez-Jurado LA, et al. Synaptic plasticity and spatial working memory are impaired in the CD mouse model of Williams-Beuren syndrome. Mol Brain. 2016;9(1):76.

8. Valero MC, de Luis O, Cruces J, Perez Jurado LA. Fine-scale comparative mapping of the human 7q11.23 region and the orthologous region on mouse chromosome 5G: the low-copy repeats that flank the WilliamsBeuren syndrome deletion arose at breakpoint sites of an evolutionary inversion(s). Genomics. 2000;69(1):1-13.

9. Hoogenraad CC, Koekkoek B, Akhmanova A, Krugers H, Dortland B, Miedema M, et al. Targeted mutation of Cyln2 in the Williams syndrome critical region links CLIP-115 haploinsufficiency to neurodevelopmental abnormalities in mice. Nat Genet. 2002;32(1):116-27.

10. Lucena J, Pezzi S, Aso E, Valero MC, Carreiro C, Dubus P, et al. Essential role of the N-terminal region of TFIII in viability and behavior. BMC Med Genet. 2010;11:61.

11. Tassabehji M, Hammond P, Karmiloff-Smith A, Thompson P, Thorgeirsson SS, Durkin ME, et al. GTF2IRD1 in craniofacial development of humans and mice. Science. 2005;310(5751):1184-7.

12. Schubert $C$. The genomic basis of the Williams-Beuren syndrome. Cell Mol Life Sci. 2009;66(7):1178-97.

13. Zhang T, Chen P, Li W, Sha S, Wang Y, Yuan Z, et al. Cognitive deficits in mice lacking Nsun5, a cytosine-5 RNA methyltransferase, with impairment of oligodendrocyte precursor cells. Glia. 2018;67(4):688-702.

14. Thompson PM, Lee AD, Dutton RA, Geaga JA, Hayashi KM, Eckert MA, et al. Abnormal cortical complexity and thickness profiles mapped in Williams syndrome. J Neurosci. 2005;25(16):4146-58.

15. Segura-Puimedon M, Sahun I, Velot E, Dubus P, Borralleras C, Rodrigues AJ, et al. Heterozygous deletion of the Williams-Beuren syndrome critical interval in mice recapitulates most features of the human disorder. Hum Mol Genet. 2014;23(24):6481-94.
16. Li HH, Roy M, Kuscuoglu U, Spencer CM, Halm B, Harrison KC, et al. Induced chromosome deletions cause hypersociability and other features of Williams-Beuren syndrome in mice. EMBO Mol Med. 2009;1(1):50-65.

17. Ramani AK, Li Z, Hart GT, Carlson MW, Boutz DR, Marcotte EM. A map of human protein interactions derived from co-expression of human mRNAs and their orthologs. Mol Syst Biol. 2008;4:180.

18. Gigova A, Duggimpudi S, Pollex T, Schaefer M, Kos M. A cluster of methylations in the domain IV of $25 \mathrm{~S}$ rRNA is required for ribosome stability. RNA. 2014;20(10):1632-44.

19. Sharma S, Yang J, Watzinger $P$, Kotter $P$, Entian KD. Yeast Nop2 and Rcm1 methylate C2870 and C2278 of the 25 S rRNA, respectively. Nucleic Acids Res. 2013;41(19):9062-76.

20. Schosserer M, Minois N, Angerer TB, Amring M, Dellago H, Harreither E, et al. Methylation of ribosomal RNA by NSUN5 is a conserved mechanism modulating organismal lifespan. Nat Commun. 2015;6:6158.

21. Khan MA, Rafiq MA, Noor A, Hussain S, Flores JV, Rupp V, et al. Mutation in NSUN2, which encodes an RNA methyltransferase, causes autosomalrecessive intellectual disability. Am J Hum Genet. 2012;90(5):856-63.

22. Martinez FJ, Lee JH, Lee JE, Blanco S, Nickerson E, Gabriel S, et al. Whole exome sequencing identifies a splicing mutation in NSUN2 as a cause of a Dubowitz-like syndrome. J Med Genet. 2012;49(6):380-5.

23. Blanco S, Dietmann S, Flores JV, Hussain S, Kutter C, Humphreys P, et al. Aberrant methylation of tRNAs links cellular stress to neuro-developmental disorders. EMBO J. 2014;33(18):2020-39.

24. Chi L, Delgado-Olguin P. Expression of NOL1/NOP2/sun domain (Nsun) RNA methyltransferase family genes in early mouse embryogenesis. Gene Expr Patterns. 2013;13(8):319-27.

25. Custo Greig LF, Woodworth MB, Galazo MJ, Padmanabhan H, Macklis JD. Molecular logic of neocortical projection neuron specification, development and diversity. Nat Rev Neurosci. 2013;14(11):755-69.

26. Kohwi M, Doe CQ. Temporal fate specification and neural progenitor competence during development. Nat Rev Neurosci. 2013;14(12):823-38.

27. Kriegstein A, Alvarez-Buylla A. The glial nature of embryonic and adult neural stem cells. Annu Rev Neurosci. 2009;32:149-84.

28. Shen B, Zhang W, Zhang J, Zhou J, Wang J, Chen L, et al. Efficient genome modification by CRISPR-Cas9 nickase with minimal off-target effects. Nat Methods. 2014;11(4):399-402.

29. Zhang C, Ge X, Liu Q, Jiang M, Li MW, Li H. MicroRNA-mediated non-cellautonomous regulation of cortical radial glial transformation revealed by a Dicer1 knockout mouse model. Glia. 2015;63(5):860-76.

30. Paridaen JT, Huttner WB. Neurogenesis during development of the vertebrate central nervous system. EMBO Rep. 2014;15(4):351-64.

31. Liu R, Yang Y, Shen J, Chen H, Zhang Q, Ba R, et al. Fstl1 is involved in the regulation of radial glial scaffold development. Mol Brain. 2015;8:53.

32. Gaiano N, Nye JS, Fishell G. Radial glial identity is promoted by Notch1 signaling in the murine forebrain. Neuron. 2000;26(2):395-404.

33. Yokota Y, Eom TY, Stanco A, Kim WY, Rao S, Snider WD, et al. Cdc42 and Gsk3 modulate the dynamics of radial glial growth, inter-radial glial interactions and polarity in the developing cerebral cortex. Development. 2010;137(23):4101-10.

34. Cappello S, Bohringer CR, Bergami M, Conzelmann KK, Ghanem A, Tomassy $\mathrm{GS}$, et al. A radial glia-specific role of RhoA in double cortex formation. Neuron. 2012:73(5):911-24.

35. Miyama S, Takahashi T, Nowakowski RS, Caviness VS Jr. A gradient in the duration of the G1 phase in the murine neocortical proliferative epithelium. Cereb Cortex. 1997;7(7):678-89.

36. Cappello S, Attardo A, Wu X, Iwasato T, Itohara S, Wilsch-Brauninger M, et al. The rho-GTPase cdc42 regulates neural progenitor fate at the apical surface. Nat Neurosci. 2006;9(9):1099-107.

37. Poluch S, Juliano SL. A normal radial glial scaffold is necessary for migration of interneurons during neocortical development. Glia. 2007;55(8):822-30.

38. Sessa A, Mao CA, Hadjantonakis AK, Klein WH, Broccoli V. Tbr2 directs conversion of radial glia into basal precursors and guides neuronal amplification by indirect neurogenesis in the developing neocortex. Neuron. 2008;60(1):56-69.

39. Tabata $\mathrm{H}$, Nakajima K. Multipolar migration: the third mode of radial neuronal migration in the developing cerebral cortex. J Neurosci. 2003; 23(31):9996-10001.

40. Hatanaka Y, Hisanaga S, Heizmann CW, Murakami F. Distinct migratory behavior of early- and late-born neurons derived from the cortical ventricular zone. J Comp Neurol. 2004;479(1):1-14. 
41. Kakita A, Goldman JE. Patterns and dynamics of SVZ cell migration in the postnatal forebrain: monitoring living progenitors in slice preparations. Neuron. 1999;23(3):461-72.

42. Nadarajah B, Brunstrom JE, Grutzendler J, Wong RO, Pearlman AL. Two modes of radial migration in early development of the cerebral cortex. Nat Neurosci. 2001:4(2):143-50.

43. Tsai JW, Chen Y, Kriegstein AR, Vallee RB. LIS1 RNA interference blocks neural stem cell division, morphogenesis, and motility at multiple stages. J Cell Biol. 2005;170(6):935-45.

44. De Juan RC, Borrell V. Coevolution of radial glial cells and the cerebral cortex. Glia. 2015:63(8):1303-19.

45. Nagano T, Morikubo S, Sato M. Filamin a and FILIP (Filamin A-interacting protein) regulate cell polarity and motility in neocortical subventricular and intermediate zones during radial migration. J Neurosci. 2004;24(43):9648-57.

46. Bai J, Ramos RL, Ackman JB, Thomas AM, Lee RV, LoTurco JJ. RNAi reveals doublecortin is required for radial migration in rat neocortex. Nat Neurosci. 2003:6(12):1277-83.

47. Schmid RS, McGrath B, Berechid BE, Boyles B, Marchionni M, Sestan N, et al. Neuregulin 1-erbB2 signaling is required for the establishment of radial glia and their transformation into astrocytes in cerebral cortex. Proc Natl Acad Sci U S A. 2003;100(7):4251-6.

48. Neubrand VE, Pedreno M, Caro M, Forte-Lago I, Delgado M, Gonzalez-Rey E. Mesenchymal stem cells induce the ramification of microglia via the small RhoGTPases Cdc42 and Rac1. Glia. 2014;62(12):1932-42.

49. Gerashchenko MV, Lobanov AV, Gladyshev VN. Genome-wide ribosome profiling reveals complex translational regulation in response to oxidative stress. Proc Natl Acad Sci U S A. 2012;109(43):17394-9.

50. Lawless C, Pearson RD, Selley JN, Smirnova JB, Grant CM, Ashe MP, et al. Upstream sequence elements direct post-transcriptional regulation of gene expression under stress conditions in yeast. BMC Genomics. 2009;10:7.

51. Kilkenny C, Browne WJ, Cuthill IC, Emerson M, Altman DG. Improving bioscience research reporting: the ARRIVE guidelines for reporting animal research. Osteoarthr Cartil. 2012;20(4):256-60.

52. Fan $X$, Kim HJ, Bouton D, Warner M, Gustafsson JA. Expression of liver $X$ receptor beta is essential for formation of superficial cortical layers and migration of later-born neurons. Proc Natl Acad Sci U S A. 2008;105(36): 13445-50.

53. Wu ZQ, Li D, Huang Y, Chen XP, Huang W, Liu CF, et al. Caspr controls the temporal specification of neural progenitor cells through notch signaling in the developing mouse cerebral cortex. Cereb Cortex. 2017;27(2):1369-85.

54. Furtak SC, Moyer JR Jr, Brown TH. Morphology and ontogeny of rat perirhinal cortical neurons. J Comp Neurol. 2007;505(5):493-510.

55. Solorzano C, Villafuerte D, Meda K, Cevikbas F, Braz J. Primary afferent and spinal cord expression of gastrin-releasing peptide: message, protein, and antibody concerns. J Neurosci. 2015;35(2):648-57.

\section{Publisher's Note}

Springer Nature remains neutral with regard to jurisdictional claims in published maps and institutional affiliations.

Ready to submit your research? Choose BMC and benefit from:

- fast, convenient online submission

- thorough peer review by experienced researchers in your field

- rapid publication on acceptance

- support for research data, including large and complex data types

- gold Open Access which fosters wider collaboration and increased citations

- maximum visibility for your research: over $100 \mathrm{M}$ website views per year

At $\mathrm{BMC}$, research is always in progress.

Learn more biomedcentral.com/submissions 